From Indra's Net to Internet 


\section{Contemporary Buddhism}

MARK M. ROWE, EDITOR

Architects of Buddhist Leisure: Socially Disengaged Buddhism in Asia's Museums, Monuments, and Amusement Parks

Justin Thomas McDaniel

Educating Monks: Minority Buddhism on China's Southwest Border

Thomas A. Borchert

From the Mountains to the Cities: Buddhist Propagation in the History of Modern Korean Buddhism

Mark A. Nathan

From Indra's Net to Internet: Communication, Technology, and the Evolution of Buddhist Ideas Daniel Veidlinger 


\section{From Indra's Net to Internet}

Communication, Technology, and the Evolution of Buddhist Ideas

Daniel Veidlinger 
(C) 2018 University of Hawai'i Press

All rights reserved

Printed in the United States of America

$232221201918 \quad 6544321$

\section{Library of Congress Cataloging-in-Publication Data}

Names: Veidlinger, Daniel M., author.

Title: From Indra's net to Internet : communication, technology, and the evolution of Buddhist ideas / Daniel Veidlinger.

Other titles: Contemporary Buddhism.

Description: Honolulu : University of Hawai'i Press, [2018] | Series:

Contemporary Buddhism | Includes bibliographical references and index.

Identifiers: LCCN 2017054855 | ISBN 9780824873400 (cloth alk. paper)

Subjects: LCSH: Buddhism-Computer networks. | Internet-Religious aspects-Buddhism. | Cyberspace-Religious aspects-Buddhism. | Buddhism-History.

Classification: LCC BQ4570.T42 V45 2018 | DDC 294.30285-dc23

LC record available at https://lccn.loc.gov/2017054855

University of Hawai'i Press books are printed on acid-free paper and meet the guidelines for permanence and durability of the Council on Library Resources.

Cover: Phnom Penh, Cambodia, 2016. Photo by Calvin Greenwood. 